\title{
The Influence of Environmental Factors on the Population Structure and Reproductive Biology of Idotea balthica basteri (Isopoda, Valvifera) of the Bizerte Lagoon (Northern Tunisia)
}

\author{
Wahiba Zaabar, Faouzia Charfi-Cheikhrouha, Mohamed Sghaier Achouri \\ Unité de Recherche de Bio-Ecologie et Systématique Evolutive (UR11ES11), Faculté des Sciences de Tunis, \\ Université de Tunis El Manar, Manar II, Tunisia \\ Email: mohamed.achouri@gmail.com
}

Received 2 February 2016; accepted 27 March 2016; published 30 March 2016

Copyright (C) 2016 by authors and Scientific Research Publishing Inc.

This work is licensed under the Creative Commons Attribution International License (CC BY). http://creativecommons.org/licenses/by/4.0/

(c) (†) Open Access

\begin{abstract}
The reproductive biology of a natural population of Idotea balthica basteri (Pallas, 1772) collected from Menzel Jemil (Bizerte lagoon, Tunisia) was monthly studied from October 2009 to October 2010. Besides water temperature, salinity, turbidity, $\mathrm{pH}$, and dissolved oxygen were measured. Based on the state of differentiation of individuals, the population was divided into 8 categories. Their numbers depend on the one hand to intrinsic factors imposed by the specimens and the structure of the population themselves, and to extrinsic factors due to the variability of environmental conditions on the other hand. Females were morphologically recognisable at smaller size than males. Reproductive activity, which was reflected through the presence of ovigerous females and juveniles, underwent fluctuations throughout the year, but it was continuous. Moreover, salinity, temperature, nitrates, and plant biomass have a noticeable effect on the fecundity and fertility. The Principal Component Analysis also confirmed that the richness of the water in nitrates would be favorable to fecundity and fertility of Idotea balthica basteri. However, higher phosphate concentrations, in April and May seem to have a positive effect on the sex ratio. Otherwise, the temperature would be responsible for increasing the percentage of ovigerous females.
\end{abstract}

\section{Keywords}

Population Structure, Reproductive Biology, Environmental Factors, Idotea balthica, Mediterranean Lagoon, Tunisia 


\section{Introduction}

According to its ecological and economic importance, the Bizerte lagoon has been the subject of several investigations in the last decades, carried on its physico-chemical [1]-[4], on its flora [5] [6] and on its fauna such as mussels and clams [7], Crustaceans Copepoda [8] [9]. Among Isopod Crustaceans, when abundant, Idotea plays a fundamental role in marine ecosystem. Indeed, I. balthica of the Baltic ecosystem constitutes an important herbivore on the bladder-wrack (Fucus vesiculosus) [10] and food-source for many fish species [11]. Several works which have been carried on the biology and reproductive behaviour of the genus Idotea, showed variations in the duration of the breeding season in lagoon species Idotea chelipes Pallas 1766 [12]-[14] and marine species such as Idotea granulosa [15], Idotea pelagica (Leifsson 1998), Idotea metallica [16], Idotea balthica [17]-[21].

In the present study we focused on Idotea balthica basteri which is common on the Tunisian coasts and shows characteristics that make it easy to capture: 1) The population lives on the upper infralittoral, reducing the sampling effort in a defined area and there isn't planktonic larval stages because the embryonic and post embryonic development occurs in the female's marsupium until mancae stage; 2) all phases of life cycle can be sampled with the assurance that the young are issued from the same population; 3 ) individuals are abundant being able to support a wide range of environmental conditions.

The main objective of this work is to investigate the reproductive biology of a natural population of Idotea balthica basteri at Menzel Jemil (Bizerte lagoon) and to highlight the influence of some environmental factors on its reproduction.

\section{Materials and Methods}

Study area: A natural population of Idotea balthica basteri occurring among seagrass floating as Cymodocea nodosa (Ucria) Ascherson 1870 and algae such as Gracilariopsis longissima (SG Gmelin) M Steentoft, LM Irvine, WF Farnham 1995, Gracilaria bursa-pastoris (SG Gmelin) PC Silva 1952, Cladophora sp. and Ulva lac-

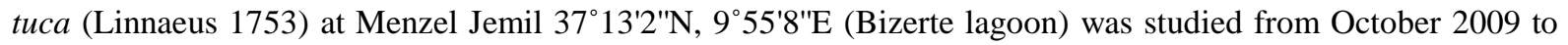
October 2010 (Figure 1).

Water temperature, salinity, turbidity, $\mathrm{pH}$, and dissolved oxygen, were measured monthly in situ using a salinometer (WTW cond 315i, SUNTEX, Weilheim, Germany), a type of microprocessor (WTW TURB 355IR, SUNTEX, Weilheim, Germany), a pH meter (pH 330i/SET, SUNTEX, Weilheim, Germany) and oxymeter (WTW Oxi315i/SET, SUNTEX, Weilheim, Germany) respectively.

The sample of plants from each month is placed in an aluminum box, oven dried at $70^{\circ} \mathrm{C}$ for $48 \mathrm{~h}$ and weighed to $\pm 0.1 \mathrm{~g}$ to evaluate the plant biomass expressed in gram of dry mass by $\mathrm{m}^{2}$. The monthly biomass plant is used as an environmental variable.

At each sampling date, the nitrite, nitrate, phosphate, and chlorophyll $a$ concentrations were determined following the methods described in [22] in [23].

Sample collection and Laboratory procedures: Specimens were sampled monthly during 1 year (from October 2009 to October 2010) using a metal quadrat of $25 \times 25 \mathrm{~cm}$ with 13 replicates between 20 and $80 \mathrm{~cm}$ depth according to the tide. Animals were removed by washing the vegetation in a big tray and recovered on a sieve of a $1 \mathrm{~mm}$ mesh, which retained all individuals including Idotea balthica basteri. Retained specimens were sorted, fixed in $70 \%$ alcohol, and then identified to different categories and counted.

Animals were sorted under a stereomicroscope Leica M5 according to their state differentiation and separated into: 1) juveniles less than $4.8 \mathrm{~mm}$ length and without secondary sexual characters; 2) males separated into: 2a) young males with genital apophyses and copulatory stylets, and 2b) adult males exhibiting a brush of setae on the propus, carpus, merus and ischiopus of pereopods 2 with enlargement of the pereonite 6 ; 3 ) females comprising two subgroups: 3a)-3b) non-reproductive females, without brood pouch, can be either 3a) young in stage 1 more than $4.8 \mathrm{~mm}$ length and not differentiated in young males, or $3 \mathrm{~b}$ ) prepubertal in stage 2 showing small oostegites on the pereopods 1 to 5 and an enlargement of the third pereonite, 3c)-3d) reproductive females showing a 3c) reproductive females in stage 3 (ovigerous) carrying eggs, embryos or mancae in the brood pouch, and $3 d$ ) reproductive females in stage 4 with an empty brood pouch.

All collected specimens were measured from the anterior edge of the cephalon to the posterior edge of the pleotelson at $\pm 0.1 \mathrm{~mm}$ using a Leica M5 Stereomicroscope.

Data analysis: The estimation of fecundity and fertility is based on the counting of eggs, embryos or mancae 


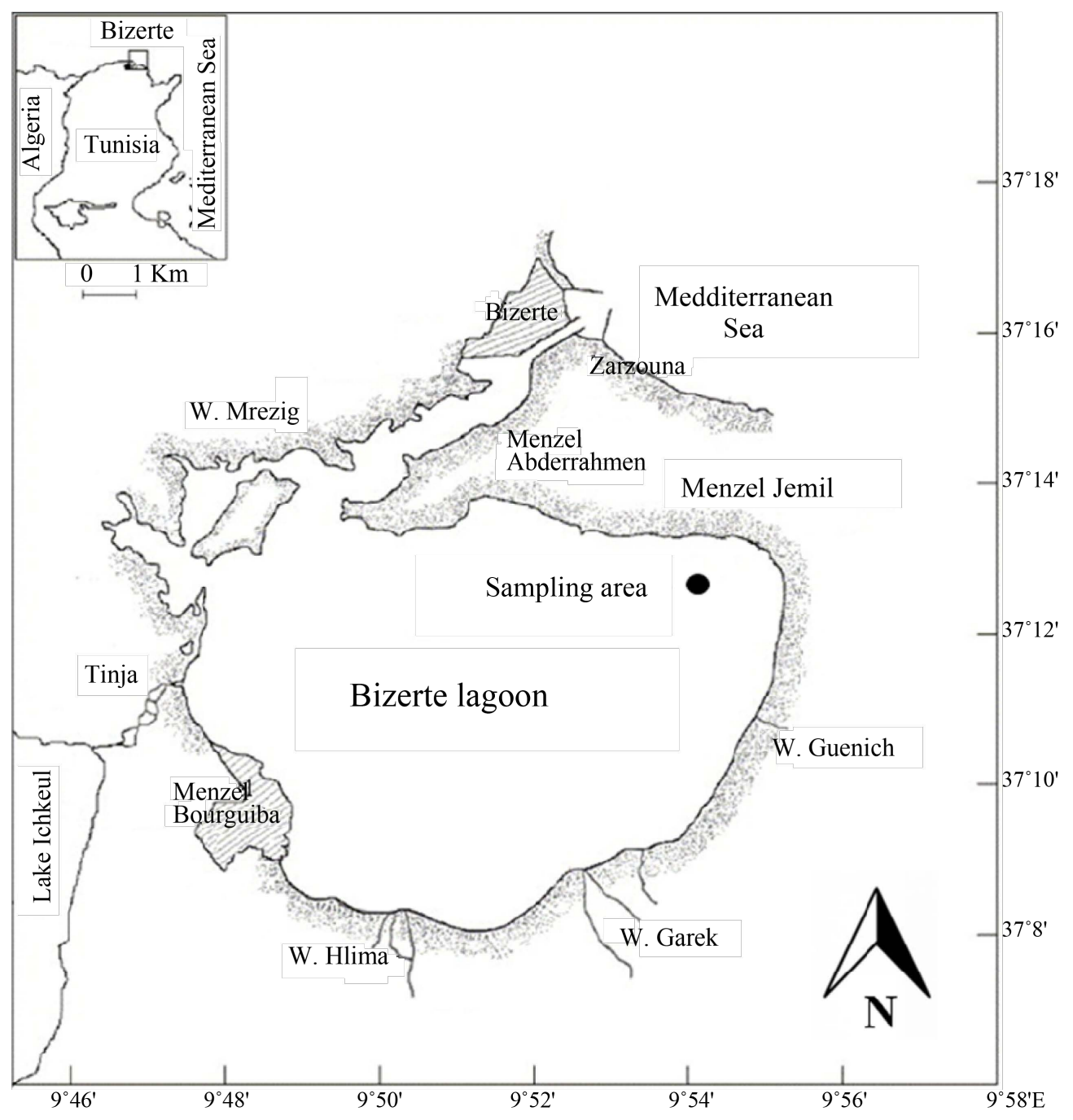

Figure 1. Sampling site of Idotea balthica basteri in Menzel Jemil (Bizerte lagoon).

contained in the marsupium of 87 ovigerous females after emptying the brood pouch of each of them in a Petri dish containing alcohol $70^{\circ}$. The relation size/fecundity or fertility is a regression obtained by Excel software.

The reproductive activity (number of ovigerous females/total number of females $\times 100 \%$ ) as well as the sex ratio (number of males/number of females) were followed during the sampling period. The observed and expected values were compared using a $\chi^{2}$ test.

Principal Component Analysis (PCA) was used to identify the influence of environmental factors (temperature, salinity, $\mathrm{pH}$, dissolved oxygen, Turbidity, nutriments (phosphates, nitrites, and nitrates), Chlorophyll $a$, and plant biomass) on the biological parameters of Idotea balthica basteri (percentage of juveniles and ovigerous females, fecundity, fertility and sex ratio). Correlation matrices were calculated using the Pearson's coefficient. Normality of the distributions was analysed using the Bartlett's test. Data analysis was performed using the XLSTAT 2013.

\section{Results}

\subsection{Environmental Factors}

Large monthly variations in biological and physicochemical conditions were observed at Menzel Jemil (Table 1). Water temperature and salinity ranging, respectively, from $9^{\circ} \mathrm{C}$ in January to $30.86^{\circ} \mathrm{C}$ in August and from 35.6 in January to 39.2 in August. Dissolved oxygen varies from $4.8 \mathrm{mg} \cdot \mathrm{l}^{-1}$ in October to $7.3 \mathrm{mg} \cdot \mathrm{l}^{-1}$ in May. The 
Table 1. Variation of Physicochemical conditions throughout the study period (T: temperature, M: mol).

\begin{tabular}{ccccccccccc}
\hline Months & $\mathrm{T}\left({ }^{\circ} \mathrm{C}\right)$ & Salinity & $\begin{array}{c}\text { Dissolved } \\
\mathrm{O}_{2}\left(\mathrm{mg} \cdot l^{-1}\right)\end{array}$ & $\mathrm{pH}$ & $\begin{array}{c}\text { Turbidity } \\
(\mathrm{NTU})\end{array}$ & $\begin{array}{c}\mathrm{NO}_{2}^{-} \\
\left(\mu \mathrm{M} \cdot l^{-1}\right)\end{array}$ & $\begin{array}{c}\mathrm{NO}_{3}^{-} \\
\left(\mu \mathrm{M} \cdot l^{-1}\right)\end{array}$ & $\begin{array}{c}\mathrm{PO}_{4}^{3-} \\
\left(\mu \mathrm{M}^{-1}\right)\end{array}$ & $\begin{array}{c}\mathrm{Chl} \mathrm{a} \\
\left(\mu \mathrm{g} \cdot l^{-1}\right)\end{array}$ & $\begin{array}{c}\text { Plant } \\
\text { biomass } \\
\left(\mathrm{g} \cdot \mathrm{m}^{-2}\right)\end{array}$ \\
\hline Oct. 09 & 19.73 & 38.4 & 4.8 & 7.9 & 14.06 & 0.5 & 1.6 & 0.13 & 5 & 44 \\
Nov. 09 & 13.25 & 37.6 & 4.9 & 8.3 & 15.44 & 0.69 & 1.8 & 0.14 & 4.4 & 61.48 \\
Dec. 09 & 10 & 36.8 & 5.9 & 8.39 & 4.7 & 0.49 & 2 & 0.16 & 4.2 & 41.15 \\
Jan. 10 & 9 & 35.6 & 6.7 & 8.62 & 2.17 & 0.43 & 2.1 & 0.2 & 4 & 23.11 \\
Feb. 10 & 11.2 & 36.1 & 6.5 & 8.65 & 3.01 & 0.5 & 3.2 & 0.18 & 3.8 & 44 \\
Mars. 10 & 15.1 & 36.8 & 6 & 8.62 & 2.1 & 0.57 & 3 & 0.24 & 4.5 & 53.73 \\
Apr. 10 & 26.13 & 36.8 & 5.5 & 8.2 & 2.4 & 0.3 & 1.8 & 0.23 & 5.3 & 73.18 \\
May. 10 & 25.63 & 37.2 & 7.3 & 8.47 & 5.12 & 0.28 & 1.7 & 0.26 & 4.7 & 80.73 \\
Jun. 10 & 27.73 & 37.9 & 6.7 & 8.53 & 4.76 & 0.1 & 1 & 0.27 & 5 & 127.12 \\
Jul. 10 & 28.46 & 39 & 5.7 & 8.6 & 6.42 & 0.7 & 0.81 & 0.28 & 5.7 & 116.21 \\
Aug. 10 & 30.86 & 39.2 & 5.9 & 8.43 & 3.2 & 1 & 0.73 & 0.38 & 6.3 & 96.7 \\
Sept. 10 & 26.7 & 38.6 & 5.6 & 8.38 & 6.18 & 0.49 & 1.4 & 0.12 & 5.4 & 85.16 \\
\hline
\end{tabular}

$\mathrm{pH}$ values without marked seasonal oscillations, ranging from 7.9 in October and 8.65 in February. The turbidity water showed two strong seasonal phases; Indeed, a significant peak marked the month of November (15.44 NTU), while the minimum value of turbidity characterized the statement of March (2.1 NTU).

The concentration of nitrites underwent monthly fluctuations and peaked in August $\left(1 \mu \mathrm{mol} \cdot \mathrm{l}^{-1}\right)$ and that of nitrates increased in winter $\left(3.2 \mu \mathrm{mol} \cdot \mathrm{l}^{-1}\right)$ and decreased in summer $\left(0.73 \mu \mathrm{mol} \cdot \mathrm{l}^{-1}\right)$, while the maximum phosphates concentration was about $0.38 \mu \mathrm{mol} \cdot \mathrm{l}^{-1}$ in August. The chlorophyll $a$ content displayed a minimum value in February $\left(3.8 \mu \mathrm{g} \cdot \mathrm{l}^{-1}\right)$ and a maximum in August $\left(6.9 \mu \mathrm{g} \cdot \mathrm{l}^{-1}\right)$. As regards the plant biomass, it reached the lowest average values in January $\left(23.11 \pm 2.35 \mathrm{~g} \cdot \mathrm{m}^{-2}\right)$ then reached its maximum in June $\left(127.12 \pm 4.80 \mathrm{~g} \cdot \mathrm{m}^{-2}\right)$.

\subsection{Population Structure}

During the sampling period, 3218 individuals were collected, examined and sorted according to their differentiation state into seven categories (Table 2). These individuals were categorized into three groups: 1095 juveniles, 649 males (196 young and 453 adult) and 1474 females (417 young, 287 prepubertal, 428 ovigerous and 342 with empty marsupium). Females were morphologically recognisable at smaller sizes than males, but males became larger than females. The number of juveniles was low compared to males and females. This could be due to their different microhabitat requirements.

\subsection{Evolution of Juveniles (Unsexed Individuals)}

Juvenile individuals were present throughout the year ranging from 1.9\% in August 2010 to 69\% in October 2009 (Table 2). Their graph (Figure 2) shows three peaks: the most important one was noted in SeptemberOctober, the second in December-January and February and the third in May-June and July.

\subsection{Evolution of Males}

Percentage of young males ( $4.8 \leq$ size $\leq 6.4 \mathrm{~mm}$ ) oscillated between $3 \%$ and $12 \%$ (Table 2). The curve of young males (Figure 2) exhibited three peaks: the first (12.3\%) in November, after one-two months of the juveniles peak (September-October), this period is needed for the acquisition of sexual differentiation. The second (7\%), in February, was associated with low winter temperatures that decreased the growth of the juveniles in December-January. The third (9\%), in August, was due to evolution of the juveniles of June and July.

Adult males $(6.5 \leq$ size $\leq 24.1 \mathrm{~mm})$, were present throughout the year showing a continuous reproductive activity. Their percentage in the population varies between 3.6\% and 35\% (Figure 2). This maximum of August 
Table 2. Monthly distribution of different groups of Idotea balthica basteri in percentage: j, juveniles; y, young; a, adult; p p, prepubertal; ovi, ovigerous; e m, with empty marsupium; $\partial^{\lambda}$, male; $q$, female.

\begin{tabular}{|c|c|c|c|c|c|c|c|}
\hline Months & $\% \mathrm{j}$ & $\% \mathrm{yô}$ & 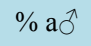 & $\% \mathrm{y}$ 웅 & $\% \mathrm{pp}$ 우 & \% ovi우 & $\%$ e $\mathrm{m}$ 우 \\
\hline Oct. 09 & 69 & 4.2 & 3.6 & 7.8 & 5.8 & 4.8 & 4.8 \\
\hline Nov. 09 & 22.8 & 12.3 & 10.1 & 7.6 & 22.8 & 8.4 & 16 \\
\hline Dec. 09 & 44.8 & 7.9 & 4 & 20.3 & 10.6 & 4 & 11.4 \\
\hline Jan. 10 & 50.8 & 4.1 & 12 & 10 & 6.6 & 5.5 & 11 \\
\hline Feb. 10 & 37.9 & 7 & 9.9 & 14.9 & 14.7 & 1.7 & 13.9 \\
\hline Mar. 10 & 24.1 & 5.5 & 22.7 & 18.3 & 8 & 10.7 & 10.7 \\
\hline Apr. 10 & 15.9 & 3.7 & 22.5 & 10.8 & 5.9 & 35 & 6.2 \\
\hline May. 10 & 23.5 & 4.8 & 12.4 & 22 & 5.7 & 22.5 & 9.1 \\
\hline Jun. 10 & 26.8 & 6.6 & 16.1 & 6.6 & 5.5 & 26.8 & 11.6 \\
\hline Jul. 10 & 24.1 & 6.7 & 18 & 19 & 10 & 13.2 & 9 \\
\hline Aug. 10 & 1.9 & 9 & 35 & 14.2 & 7.7 & 14.2 & 18 \\
\hline Sept. 10 & 40 & 7.3 & 8.4 & 13 & 3 & 17.3 & 11 \\
\hline Oct. 10 & 27 & 3 & 17 & 10 & 3 & 30 & 10 \\
\hline
\end{tabular}

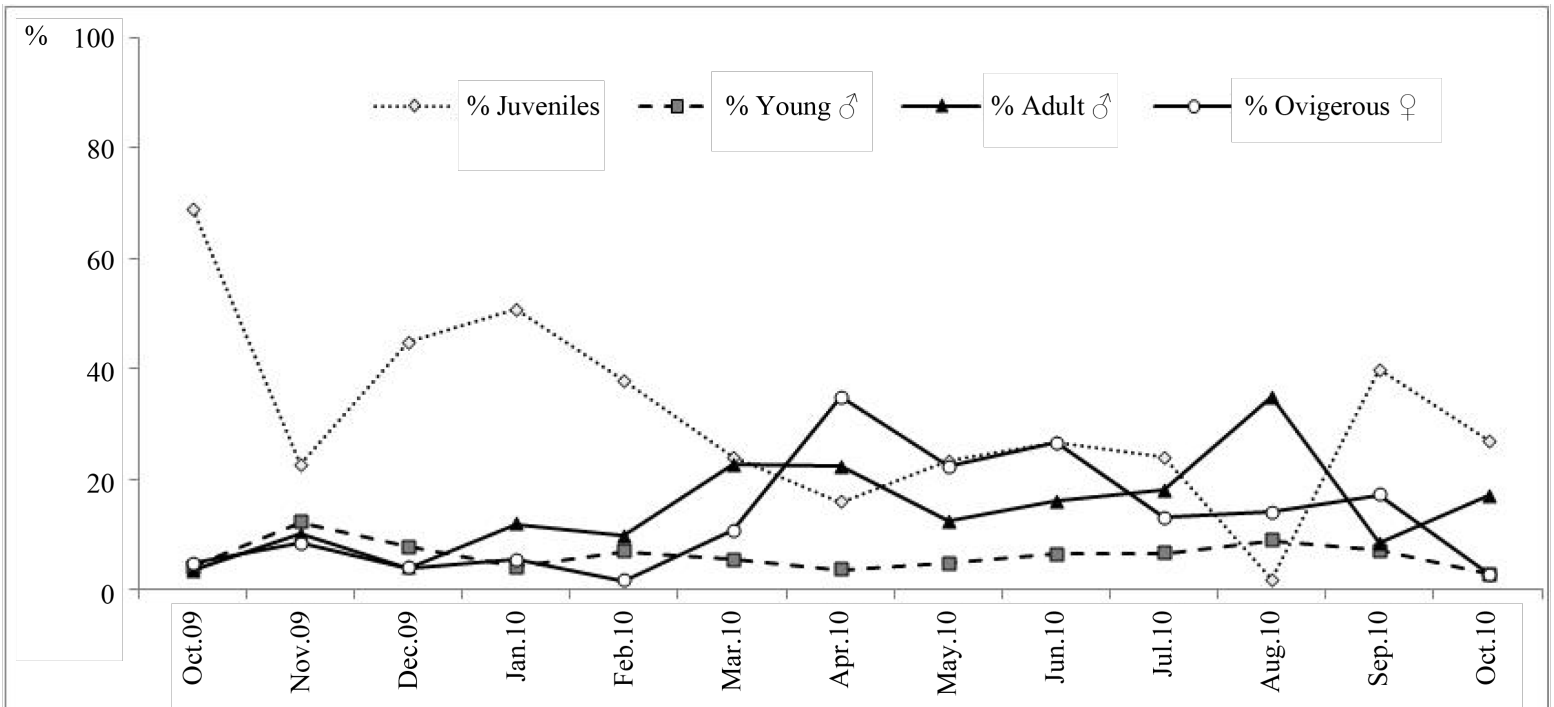

Figure 2. Evolution of Juveniles, males, and ovigerous females of Idotea balthica basteri.

(35\%), is related to the peak that occurred in spring of juveniles being mature males at the average size of $10.21 \pm$ $1.53 \mathrm{~mm}$. Moreover, the peak of adult males in March (22.5\%), is related to the peak that occurred in autumn of juveniles becoming mature males at the average size of $12.06 \pm 2.95 \mathrm{~mm}$.

\subsection{Evolution of Females}

Non-reproductive females maximum of August (35\%), is related to the peak that occurred in spring of juveniles being mature males at the average size of $10.21 \pm 1.53 \mathrm{~mm}$.

The maximum of adult males in March (22.5\%), is related to the peak that occurred in autumn of juveniles becoming mature males.

The non-reproductive-females, both young (stage 1) and prepubertal (stage 2) were always present in the 
population with variable rates.

The rate of young females does not exceed 22\% and their graph (Figure 3) shows four peaks: the first one (20.3\%) in December can be explained by the acquisition of female differentiation of October juveniles; the peak of March (18.3\%), corresponds to January juveniles, having acquired their sexual female differentiation; the third (22\%) in May is due to sexual differentiation of February juveniles, and the fourth (19\%) in July, is due to the evolution of juveniles in the previous months, May-June. The peaks of young females occur around two months after those of juveniles, a necessary period to the acquisition of female sexual differentiation.

The graph of prepubertal females (Figure 3) shows three peaks: the first in November (22.8\%); the second, less important, in February (14.7\%) and the third even lower in July (10\%). These peaks occurred one month before those of ovigerous females during the period of November-April, a period which is necessary to parturial moult and the acquisition of the first maturity.

\subsection{Reproductive Females}

Ovigerous females $(6.8 \leq$ size $\leq 14.1 \mathrm{~mm})$ : The presence of breeding females with full marsupium (stage 3 ) throughout the sampling period indicates a continuous reproduction. The monitoring of these females in our sample (Figure 3) shows two breeding activities: the most important one was recorded in spring and extended over these 3 months: April, May and June with respectively 35\%, 22.5\% and 26.8\%; the second activity occurred in autumn, from September to October (17.3\% and 30\%).

The peaks of ovigerous females coincide with those of adult males in the majority of the sampling period from October to June. The largest ovigerous females of $12.18 \pm 1.43 \mathrm{~mm}$ observed in February were probably becoming sexually active and breeding in the same year and would survive till the following year.

The average size of ovigerous females in spring breeding activity ranged from $8.95 \pm 0.94 \mathrm{~mm}$ to $10.56 \pm$ $1.11 \mathrm{~mm}$; that of autumn breeding activity, smaller, ranged from $8.41 \pm 0.72 \mathrm{~mm}$ to $8.54 \pm 0.90 \mathrm{~mm}$. With regard to the size, ovigerous females of the spring period come from both juveniles born in autumn and in the spring of the previous year. Ovigerous females during autumn season were born in spring, hence their size is reduced.

The graph (Figure 3) of the average size of ovigerous females showed, at the beginning of the spring period, that the large females $(9.68 \pm 1.11 \mathrm{~mm})$ contribute to the reproduction, whereas the contribution of smaller females (8.47 \pm 0.81$)$ occurs during autumn.

Empty marsupium females: The highest percentage of empty marsupium females was observed in August (18\%). The rate of these females increased slightly just after each peak of ovigerous females and decreased afterwards. In fact, when the ovigerous females release their mancae, they mate again and are fertilized in a new parturial moult.

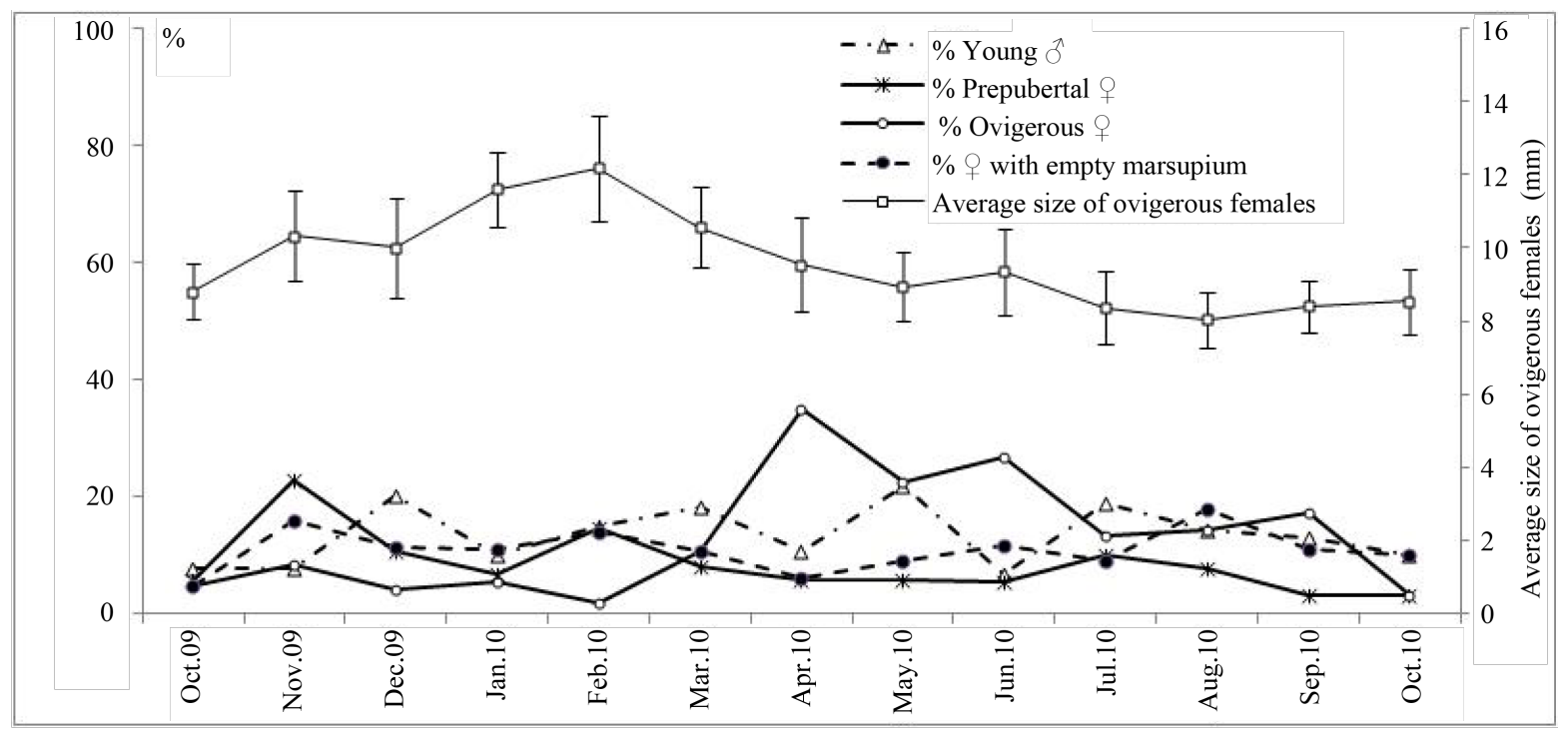

Figure 3. Evolution of the different categories of females and mean average size of reproductive females captured. 


\subsection{Evolution of Sex Ratio}

At Menzel Jemil, the overall sex ratio of Idotea balthica basteri is in favor of females (67.17\% females against $32.83 \%$ of males). Such sex ratio should promote the reproductive capacity of the population.

The monthly sex ratio undergoes fluctuations throughout the sampling period and ranges from 0.19 in December 2009 to 0.7 in August 2010 while remaining in favor of females (Table 3). Statistical analysis showed that the sex ratio deviates significantly from the unit for all months.

\subsection{Reproductive Activity}

The rate of reproductive activity, or the percentage of ovigerous females over all females, was followed (Figure 4) during the sampling period indicates a continuous reproduction, even if its rate varies according to the months. However, we recorded a significant and widespread reproductive activity with a maximum of $60.43 \%$ in April. This spring activity was followed by another autumnal activity of the same importance and which peaked in October (61.7\%).

\subsection{Fecundity}

The fecundity or number of eggs or embryos per brood varied between 3 and 150 for females size between 7.1 and $13.7 \mathrm{~mm}$. The linear regression model showed that there is a significant relationship between fecundity and the female size. Dispersion points (Figure 5(a)) can be represented by the regression equation:

$$
\mathrm{Y}=14.753 \mathrm{X}-90.237
$$

where, $\mathrm{Y}$ is the number of eggs or embryos and $\mathrm{X}$ is the size of ovigerous females.

Statistical analysis of the correlation coefficient $r^{2}$ estimated at 0.6371 , showed a proportionality between the size and fecundity. The average number of eggs or embryos per brood in Idotea balthica basteri at Menzel Jemil was estimated at $55.45 \pm 29.33$.

\subsection{Fertility}

The fertility, or number of mancae issued by brood, was also estimated. The lowest value (4) was observed in a

Table 3. Number and percentage of individuals of both sexes during the sampling period (October 2009-October 2010); $\mathrm{N}_{\mathrm{t}}$, total number (males: young and adult + females: all categories); $\mathrm{N}_{1}$, number of males; $\mathrm{N}_{2}$, number of females; $\mathrm{P}_{1}$, percentage of males; $\mathrm{P}_{2}$, percentage of females; $\left({ }^{*}\right)$, significant difference at $5 \% ;\left(^{* *}\right)$, highly significant difference at $1 \%$.

\begin{tabular}{ccccccccc}
\hline Months & $\mathrm{N}_{\mathrm{t}}$ & $\mathrm{N}_{1}$ & $\mathrm{~N}_{2}$ & $\mathrm{P}_{1}$ & $\mathrm{P}_{2}$ & Sex ratio & $\chi^{2} 1$ ddl & Significance \\
\hline Oct. 09 & 96 & 24 & 72 & 25 & 75 & 0.33 & 24 & $* *$ \\
Nov. 09 & 213 & 62 & 151 & 29.1 & 70.9 & 0.41 & 37.18 & $* * *$ \\
Dec. 09 & 68 & 11 & 57 & 16.1 & 83.9 & 0.19 & 31.11 & $* * *$ \\
Jan. 10 & 216 & 71 & 145 & 32.9 & 67.1 & 0.49 & 25.35 & $* *$ \\
Feb. 10 & 249 & 67 & 182 & 26.9 & 73.1 & 0.36 & 53.11 & $* * * *$ \\
Mars. 10 & 220 & 82 & 138 & 37.3 & 62.7 & 0.59 & 14.25 & $* * *$ \\
Apr. 10 & 202 & 63 & 139 & 31.1 & 68.9 & 0.45 & 28.59 & $* * *$ \\
May. 10 & 161 & 37 & 124 & 23 & 77 & 0.29 & 20.86 & $* * *$ \\
Jun. 10 & 145 & 45 & 100 & 31 & 69 & 0.44 & 20.86 & $* * *$ \\
Jul. 10 & 161 & 52 & 109 & 32.3 & 67.7 & 0.47 & 20.18 & $* * *$ \\
Aug. 10 & 143 & 59 & 84 & 41.2 & 58.7 & 0.7 & 4.37 & $*$ \\
Sept. 10 & 108 & 28 & 80 & 25.9 & 74 & 0.35 & 25.02 & $* * *$ \\
Oct. 10 & 133 & 39 & 94 & 29.4 & 70.6 & 0.41 & 22.74 & $* *$ \\
\hline
\end{tabular}




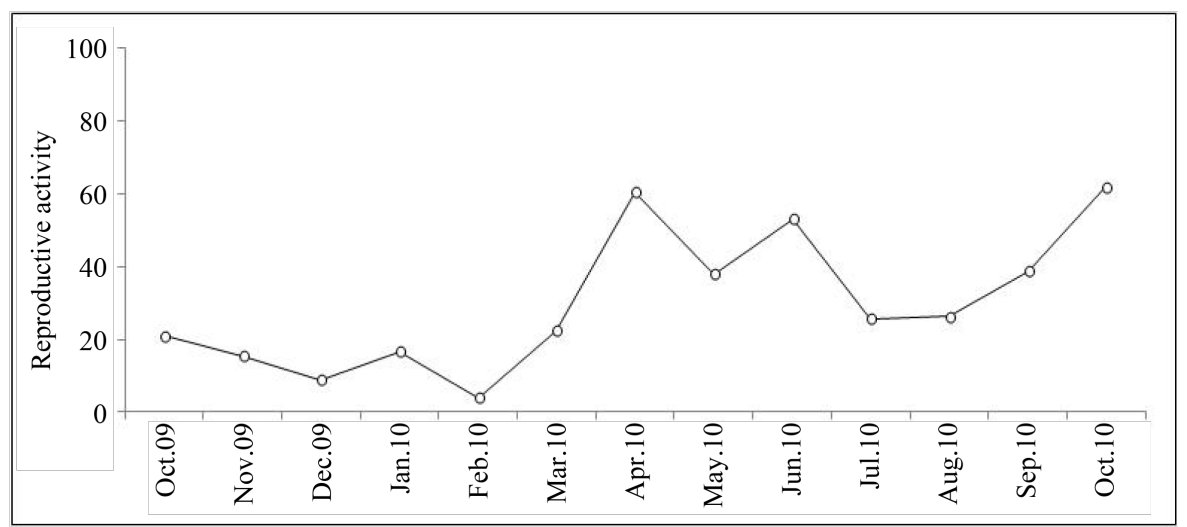

Figure 4. Evolution of reproductive activity of females.

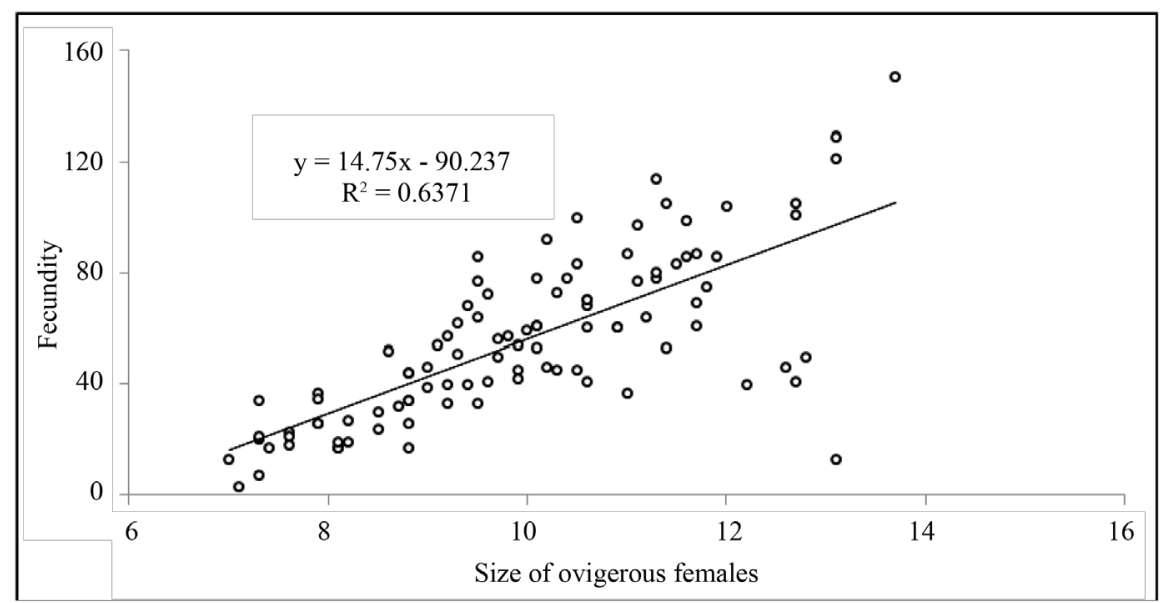

(a)

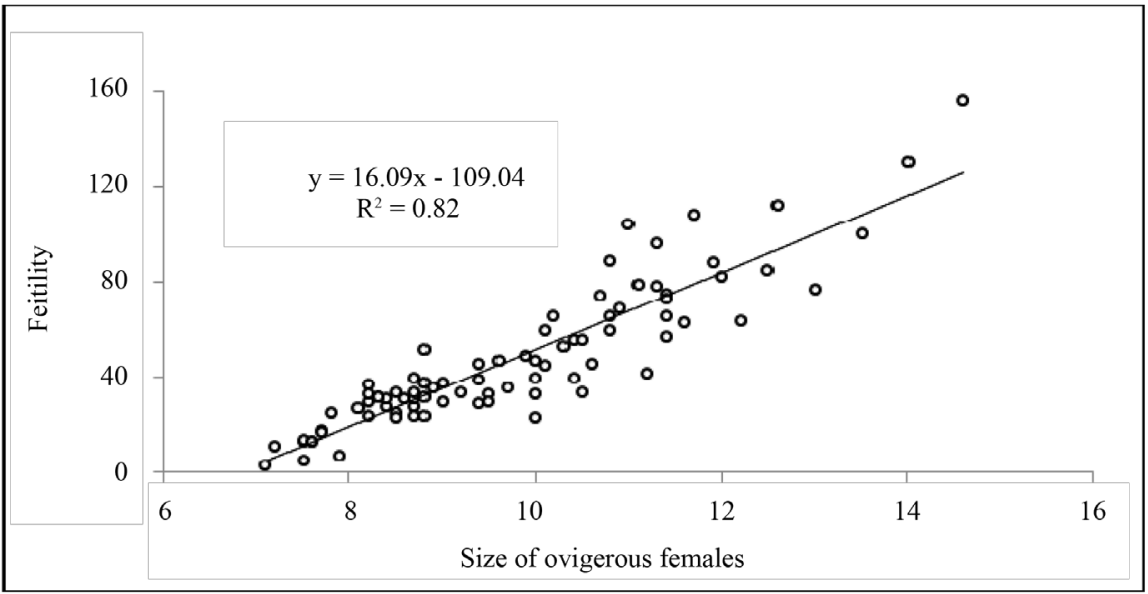

(b)

Figure 5. Relationship between, (a): the fecundity and ovigerous female size of Idotea balthica basteri; (b): the fertility and ovigerous female size of Idotea balthica basteri.

female of $7.2 \mathrm{~mm}$ and the highest value (156) characterized a female of $14.6 \mathrm{~mm}$. Dispersion points (Figure 5(b)) were represented by the regression equation:

$$
\mathrm{Y}=16.09 \mathrm{X}-109.04
$$


where, $\mathrm{Y}$ is the number of mancae and $\mathrm{X}$ the size of ovigerous females.

The correlation coefficient $r^{2}$ is estimated to be 0.82 . Statistical analysis showed that the correlation coefficient is highly significant and the number of mancae was positively correlated to the size of ovigerous females. The average number of mancae was equal to $47.80 \pm 29.51$.

The difference between fecundity and fertility was probably related to the presence of yellow eggs unable to develop into mancae, firstly and to resorption of some eggs on the other hand.

\subsection{Influence of Environmental Factors on Biological Parameters of Idotea balthica basteri}

The Principal Component Analysis (PCA) analysis was performed to identify the important environmental factors that have the most influence on biological parameters (fecundity, fertility, sex ratio, percentage of ovigerous females and juveniles) of Idotea balthica basteri at Menzel Jemil during the sampling period.

The Pearson correlation test (Table 4) showed that firstly, the chlorophyll $a$, temperature, salinity and plant biomass are highly correlated variables and secondly, $\mathrm{pH}$ and dissolved oxygen are also correlated; therefore, these variables are redundant.

Figure 6 is one of the objectives of PCA for representing biological parameters of Idotea balthica basteri on a two-dimensional map, and thus to identify trends. Based on the environmental factors we have obtained, we find that in January and February, the richness of the water in nitrates would be favorable to fecundity and fertility of Idotea balthica basteri. In April and May, the increase in the phosphates concentration, promote increased of sex ratio. We also realize that in June, the elevation of the water temperature would be responsible for the increase in the percentage of ovigerous females.

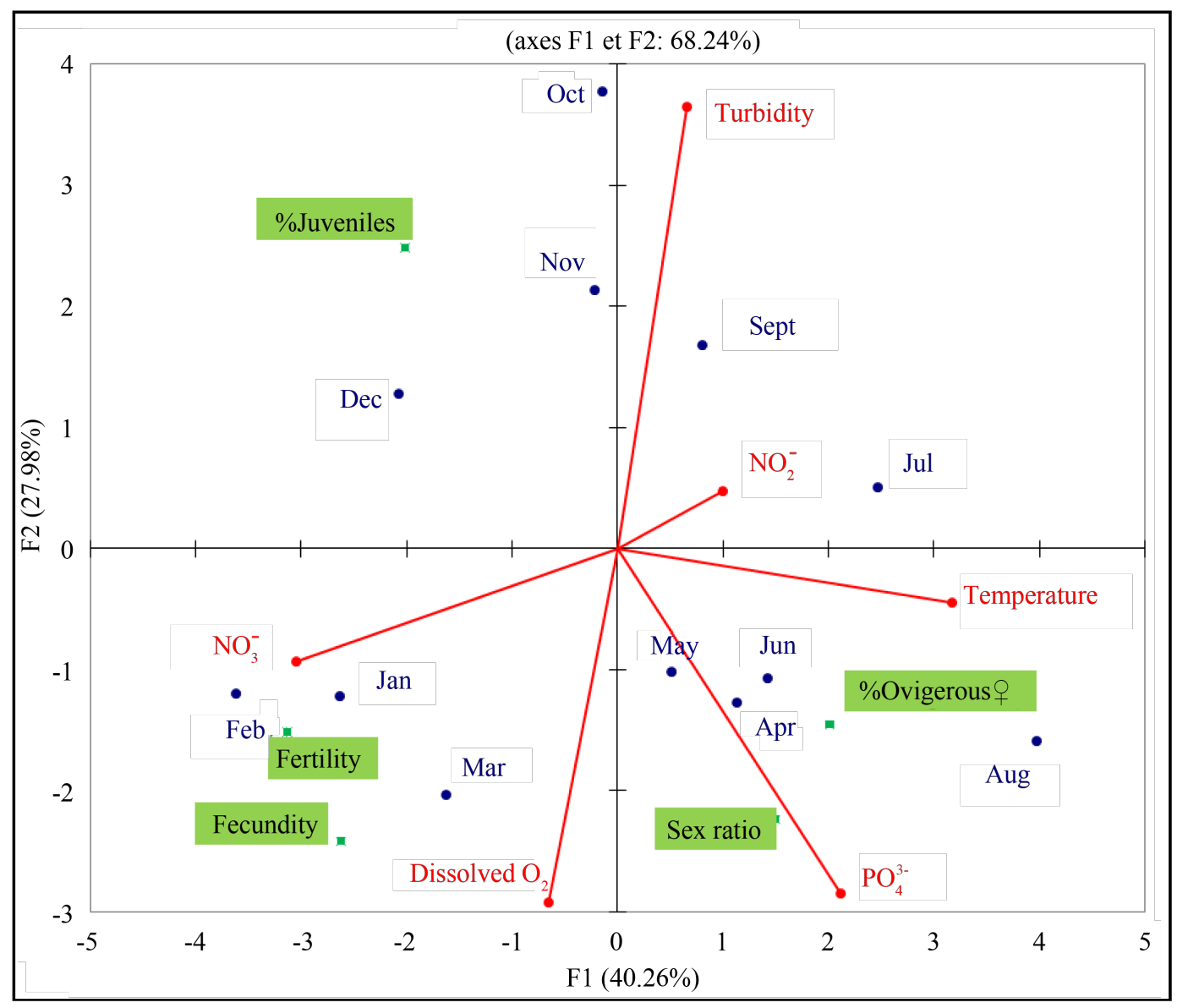

Figure 6. Principal Componnent Analysis (PCA): projection of the environmental factors and biological parameters of Idotea balthica basteri at Menzel Jemil. 
Table 4. Coefficient of regression (R) below the diagonal and $p$ values above the diagonal for Analyzed population of Idotea balthica basteri. Ovig 을 ovigerious females; Juv: juveniles; $\mathrm{T}\left({ }^{\circ} \mathrm{C}\right)$ : temperature; $\mathrm{S}$ (psu): salinity; $\mathrm{O}_{2}\left(\mathrm{mg} \cdot \mathrm{l}^{-1}\right)$ : dissolved oxygen; Tur (NTU): turbidity; $\mathrm{NO}_{3}^{-}\left(\mu \mathrm{mol} \cdot l^{-1}\right) \& \mathrm{NO}_{2}^{-}\left(\mu \mathrm{mol} \cdot l^{-1}\right)$ : nitrogen anion content.

\begin{tabular}{|c|c|c|c|c|c|c|c|c|c|c|c|c|c|c|c|}
\hline Variables & $\begin{array}{c}\text { Mean } \\
\text { fecundity }\end{array}$ & $\begin{array}{c}\% \\
\text { Ovigㅇ }\end{array}$ & \% Juv & $\begin{array}{c}\text { Sex } \\
\text { ratio }\end{array}$ & $\begin{array}{l}\text { Mean } \\
\text { fertility }\end{array}$ & $\mathrm{T}\left({ }^{\circ} \mathrm{C}\right)$ & S (psu) & $\begin{array}{c}\mathrm{O}_{2} \\
\left(\mathrm{~mol} \cdot l^{-1}\right)\end{array}$ & $\mathrm{pH}$ & $\begin{array}{c}\text { Tur } \\
\text { (NTU) }\end{array}$ & $\begin{array}{c}\mathrm{NO}_{2}^{-} \\
\left(\mu \mathrm{mol} \cdot l^{-1}\right)\end{array}$ & $\begin{array}{c}\mathrm{NO}_{3}^{-} \\
-\left(\mu \mathrm{mol} \cdot 1^{-1}\right)\end{array}$ & $\begin{array}{c}\mathrm{PO}_{4}^{3-} \\
\left(\mu \mathrm{mol} \cdot l^{-1}\right)\end{array}$ & $\begin{array}{c}\text { Chl a } \\
\left(\mu \mathrm{g} \cdot \mathrm{l}^{-1}\right)\end{array}$ & $\begin{array}{c}\text { P.b } \\
\left(\mathrm{g} / \mathrm{cm}^{-2}\right)\end{array}$ \\
\hline \multicolumn{2}{|c|}{ Mean fecundity } & 0.466 & 0.852 & 0.889 & 0.000 & 0.030 & 0.000 & 0.090 & 0.054 & 0.044 & 0.369 & 0.001 & 0.818 & 0.005 & 0.263 \\
\hline \% Ovig + & 0.054 & & 0.069 & 0.632 & 0.177 & 0.009 & 0.552 & 0.592 & 0.752 & 0.514 & 0.132 & 0.177 & 0.213 & 0.105 & 0.016 \\
\hline \% Juvs & 0.004 & 0.293 & & 0.047 & 0.446 & 0.085 & 0.420 & 0.607 & 0.275 & 0.315 & 0.351 & 0.385 & 0.006 & 0.104 & 0.057 \\
\hline Sex ratio & 0.002 & 0.024 & 0.340 & & 0.631 & 0.308 & 0.452 & 0.950 & 0.366 & 0.197 & 0.096 & 0.569 & 0.013 & 0.112 & 0.430 \\
\hline Mean fertility & 0.787 & 0.174 & 0.059 & 0.024 & & 0.000 & $<0.0001$ & 0.259 & 0.115 & 0.094 & 0.477 & 0.000 & 0.332 & 0.000 & 0.040 \\
\hline $\mathrm{T}\left({ }^{\circ} \mathrm{C}\right)$ & 0.625 & 0.715 & 0.268 & 0.103 & 0.728 & & 0.004 & 0.994 & 0.652 & 0.857 & 0.914 & 0.004 & 0.052 & $<0.0001$ & 0.003 \\
\hline S (psu) & 0.738 & 0.036 & 0.066 & 0.058 & 0.855 & 0.762 & & 0.170 & 0.310 & 0.098 & 0.147 & 0.002 & 0.347 & 0.000 & 0.071 \\
\hline $\operatorname{oxyg}\left(\mathrm{mol} \cdot 1^{-1}\right)$ & 0.260 & 0.030 & 0.027 & 0.000 & 0.125 & 0.000 & 0.180 & & 0.012 & 0.042 & 0.153 & 0.626 & 0.187 & 0.382 & 0.609 \\
\hline $\mathrm{pH}$ & 0.323 & 0.010 & 0.117 & 0.082 & 0.230 & 0.021 & 0.103 & 0.483 & & 0.038 & 0.966 & 0.434 & 0.208 & 0.442 & 0.677 \\
\hline Tur (NTU) & 0.346 & 0.044 & 0.101 & 0.161 & 0.255 & 0.003 & 0.250 & 0.353 & 0.363 & & 0.692 & 0.265 & 0.131 & 0.771 & 0.849 \\
\hline $\begin{array}{c}\mathrm{NO}_{2}^{-} \\
\left(\mu \mathrm{mol} \cdot 1^{-1}\right)\end{array}$ & 0.081 & 0.212 & 0.087 & 0.252 & 0.052 & 0.001 & 0.198 & 0.193 & 0.000 & 0.016 & & 0.605 & 0.410 & 0.210 & 0.545 \\
\hline $\begin{array}{c}\mathrm{NO}_{3}^{-} \\
\left(\mu \mathrm{mol} \cdot 1^{-1}\right)\end{array}$ & 0.697 & 0.174 & 0.076 & 0.034 & 0.789 & 0.766 & 0.636 & 0.025 & 0.062 & 0.122 & 0.028 & & 0.177 & 0.002 & 0.018 \\
\hline $\begin{array}{c}\mathrm{PO}_{4}^{3-} \\
\left(\mu \mathrm{mol} \cdot 1^{-1}\right)\end{array}$ & 0.006 & 0.150 & 0.549 & 0.473 & 0.094 & 0.327 & 0.089 & 0.167 & 0.153 & 0.213 & 0.069 & 0.174 & & 0.056 & 0.047 \\
\hline $\begin{array}{l}\mathrm{Chl} \mathrm{a} \\
\left(\mu \mathrm{g} \cdot \mathrm{l}^{-1}\right)\end{array}$ & 0.753 & 0.241 & 0.242 & 0.233 & 0.770 & 0.811 & 0.743 & 0.077 & 0.060 & 0.009 & 0.152 & 0.651 & 0.318 & & 0.046 \\
\hline $\begin{array}{c}\mathrm{P}, \mathrm{P} . \mathrm{b} \\
\left(\mathrm{g} / \mathrm{cm}^{-2}\right)\end{array}$ & 0.124 & 0.676 & 0.315 & 0.063 & 0.633 & 0.593 & 0.289 & 0.027 & 0.018 & 0.004 & 0.038 & 0.445 & 0.339 & 0.342 & \\
\hline
\end{tabular}

\section{Discussion}

The ovigerous females and Juveniles of Idotea balthica basteri were found all over the study period from October 2009 to October 2010 at Menzel Jemil (Bizerte lagoon) and the reproduction was continuous. This Idotea in Tunisia exhibited a similarity in the reproductive behaviour with other Mediterranean populations such as the natural population in the Gulf of Naples Tyrrhenian Sea [19] and the Hellenic [24]. However, in the natural populations of Idotea balthica balthica living at higher latitudes in the Baltic Sea, reproductive activity is limited to the spring-summer [25]. While in Idotea balthica basteri of the French Mediterranean lagoons, the reproduction period is spread over three seasons: spring, summer followed by a sexual rest period during the winter season [26]. Despite the variability in the reproductive behavior of Idotea balthica basteri, there was a similarity in the behavior of the two populations, lagoon in Tunisia and marine in Italy, despite the geographical distance between them, and divergence of these populations compared to the lagoons one in the south of France.

The continuous Reproduction of Idotea balthica basteri at Menzel Jemil is similar to other Tunisian populations of Idotea chelipes at Tunis Lake [12] and Garaat Ichkeul [27] and other Mediterranean populations of Spain [28] and Atlantic Arcachon in France [29] [30], where the ovigerous females of I. chelipes were collected throughout the year.

In Idotea granulosa, Brylinski et al. 2006 [31] identified two breeding periods: the first one from June to August and the second one in the fall (September-October). In addition, the ovigerous females born in the same year contribute to the fall reproduction while those born in autumn participate in the summer breeding of the following year.

The sex ratio of Idotea balthica basteri, like several species of Peracarid Crustaceans, was always in favor of females and deviated significantly from the unit for every month, this could be due to the presence of certain 
pollutants such as heavy metals ( $\mathrm{Cu}, \mathrm{Zn}$ and $\mathrm{Pb}$ ) in the middle of study [32]. Indeed, (Bat et al. 1999 [33]) in their investigation focused on the toxic effects of heavy metals $\mathrm{Cu}, \mathrm{Zn}$ and $\mathrm{Pb}$ on Idotea balthica, found that survival was significantly lower in males than in females suggesting that this type of toxicity related to sex may modify the population structure in favour of females. Also (Bouslama et al. 2007 [34]) showed a sex ratio imbalanced for each month with a predominance of female individuals in the species Talitrus saltator (Amphipoda, Talitridae) of the supralittoral zone of Zouaraa beach (Tunisia). These authors suggest that this imbalance is a strategy adopted by the species to cope with environmental constraints increasingly important. However, in the intertidal population of Idotea balthica at Cape Blomidon of Minas Basin [17], the sex ratio was bimodal with an early predominance of males in spring replaced by a predominance of females in summer. Strong (1978) [17], explained this bimodality by the migration of males in the early spring to the intertidal zone, and by the mortality of adult males in late spring after completing their role in the reproductive cycle. In the same locality, (Merilaita \& Jormalainen 1997 [30]) showed in Idotea baltica that the males and females are positioned differently on Fucus. Thus, males are more frequently encountered on the apex and thus are potentially more exposed to predators, which would lead to a sex ratio in favor of females. (Charfi-Cheikhrouha 1982 [12]) found that the sex ratio of Idotea chelipes of Lake Tunis, in favor of females, undergoes seasonal fluctuations of large amplitude, while it is close to unity (0.94) if considering the overall sex ratio. Nevertheless, males are most dominant particularly during the spring and summer in Idotea chelipes at Ichkeul Lake [27]. In fact, (Pantoustier \& Prunus 1977 [35]) indicated that the overall sex ratio in Jaera hopeana on Tunisian coasts was close to unity, but this sex ratio varies according to the season and this was explained by shifts of maturation and longevity between sexes.

Moreover, in Idotea balthica basteri at Menzel Jemil, the sex ratio was positively correlated with the phosphates concentration; but in the Baltic, (Kouwenberg \& Pinkster 1985 [26]) suggested that the temperature has an effect on sex determination.

The fecundity and fertility were positively correlated with the size of ovigerous females. This result was also found in the population of Idotea balthica basteri at the Golf of Naples where only largest females (12 - $14 \mathrm{~mm})$ produced high number of eggs [19]. This relation was also demonstrated in Idotea ganulosa of Iceland coast [36], in Idotea chelipes of Arachon basin [13] and in Idotea metallica of Catalan coast (western Mediterranean) [16].

Among the environmental factors analyzed, only the nitrates concentration affects positively the fecundity and fertility of Idotea balthica basteri at Menzel Jemil, while the effect of temperature was highlighted both in natural Idotea balthica populations that reared in the laboratory [37]-[39]. (Mocquard et al. 1978 [37]) showed that low salinity reduced the number of viable eggs. In the Mondego estuary (Portugal), the fecundity among Cyathura carinata was positively correlated with salinity and $\mathrm{pH}[40]$.

\section{Conclusion}

In the present study, salinity, temperature, nitrates, and plant biomass have a noticeable effect on the fecundity and the fertility of the population Idotea balthica basteri in the Bizerte lagoon. Otherwise, the temperature would be responsible for increasing the percentage of ovigerous females. Finally, Idotea balthica basteri characterized by a wide distribution in the Mediterranean, a short life cycle and sensitivity to environmental factors, could be a model species in the study of environmental quality.

\section{Acknowledgements}

This work was undertaken within the framework of the research activities of the laboratory of "Bio-Ecology and Evolutionary Systematics" financed by the Tunisian Ministry of Higher Education, Scientific Research. Many thanks are given to those who contributed to the field and laboratory components of this work.

\section{References}

[1] Romdhane, M.S., Belkhouja, H., Ben Rejeb, A. and Jenhani-Ghrabi, A. (2004) Interaction entre la qualité du substrat et la faune malacologique de la lagune de Bizerte. INRST-JICA Publishers, Tunis, 115-123.

[2] Bejaoui, B., Harzallah, A., Moussa, M., Chapelle, A. and Solidoro, C. (2008) Analysis of Hydrobiological Pattern in the Bizerte Lagoon (Tunisia). Estuarine Coastal and Shelf Science, 80, 121-129. http://dx.doi.org/10.1016/j.ecss.2008.07.011 
[3] Bouzaiane, O., Kouki, S., Saidi, N., Yoshida, M. and Hassen, A. (2009) Biophysical and Microbial Characteristics of Bizerte Lagoon Sediments (Tunisia). Revue Méditerranéenne de l'Environnement, 3, 510-523.

[4] Ben Garali, A., Ouakad, M. and Gueddari, M. (2010) Contamination of Superficial Sediments by Heavy Metals and Iron in the Bizerte Lagoon, Northern Tunisia. Arabian Journal of Geosciences, 3, 295-306. http://dx.doi.org/10.1007/s12517-009-0082-9

[5] Bellakhal-Fartouna, M. and Daly Yahia-Kefi, O. (2004) Taxonomie et Ecologie des Dinoflagellés au niveau du parc conchylicole de Menzel Jmil (Lagune de Bizerte, Tunisie septentrionale). Rapport de la Commission Internationale de la Mer Méditerranée, 37, 490 p.

[6] Mensi, F., Ksouri, J., Hammami, W. and Romdhane, M.S. (2009) L'algue rouge Gracilaria verrucosa (Hudson) de la lagune de Bizerte (Tunisie septentrionale): Essai en mode suspend et composition biochimique. Bulletin de l'Institut National des Sciences et Technologies de la Mer de Salammbô, 36, 125-137.

[7] Dellali, M., Romeo, M. and Aissa, P. (2001) Suivi annuel de l'activité catalase chez des moules et des palourdes originaires de la lagune de Bizerte. Oceanologica Acta, 24, 263-271. http://dx.doi.org/10.1016/S0399-1784(01)01145-8

[8] Hamdi, H., Ghribi, R., Oueryemi, N. and Daly Yahia, M.N. (2002) Fluctuations printanière et estivale des communautés de copépodes pélagiques dans la lagune de Bizerte. Revue de la Faculté des Sciences de Bizerte, 1, 200-207.

[9] Souissi, A., Souissi, S. and Daly Yahia, M.N. (2008) Temporal Variability of Abundance and Reproductive Traits of Centropages kroyeri (Calanoida; Copepoda) in Bizerte Channel (SW Mediterranean Sea, Tunisia). Journal of Experimental Marine Biology and Ecology, 355, 125-136. http://dx.doi.org/10.1016/j.jembe.2007.12.011

[10] Jormalainen, V., Merilaita, S. and Riihimaki, J. (2001) Costs of Intersexual Conflict in the Isopod Idotea baltica. Journal of Evolutionary Biology, 14, 763-772. http://dx.doi.org/10.1046/j.1420-9101.2001.00325.x

[11] Leidenberger, S. (2013) Adaptation to the Baltic Sea the Case of Isopod Genus Idotea. Thesis for the Degree of Doctor of Philosophy, Faculty of Science, Printed by Ale Tryckteam AB Bohus, Sweden, 29 p.

[12] Charfi-Cheikhrouha, F. (1982) Etude du cycle annuel d'Idotea chelipes (Pallas) du lac de Tunis (Isopodes Valvifères). Revue de la Faculté des Sciences de Tunis, 2, 101-113.

[13] Cloarec, M., Labourg, P.J. and Lasserre, G. (1983) Cycle, croissance et production d'un isopode Idotea chelipes (Pallas) d’une lagune aménagée du bassin d'Arcachon. Cahiers de Biologie Marine, Tome XXIV, 21-33.

[14] Junoy, J. and Viéitez, J.M. (1990) Idotea chelipes (Pallas, 1966) (Crustacea, Isopoda) in the Ria de Foz (Lugo, Spain). Boletfn de la Real Sociedad Espanola de Historia Natural, 85, 87-97.

[15] Lampert, L., Le Gac, C.A., Antajan, E., Meirland, A., Migne, A., Nogues, L. and Delpech, J.P. (2008) Surveillance écologique et halieutique du site de Paluel, année 2007-Rapport scientifique annuel. Rapport IFREMER RST LERN 08.01, 182 p.

[16] Abello, P. and Frankland, R.J. (1997) Population Characteristics of the Neustonic Isopod Idotea metallica (Crustacea, Isopoda, Idoteidae) in the Western Mediterranean. Sciences Marine, 61, 409-414.

[17] Strong, W. (1978) Breeding and Bionomics of Idotea balthica (Pallas) (Crustacean: Isopoda). Proceedings of the Nova Scotian, Institute of Science, 28, 217-230.

[18] Borowsky, B. (1987) Laboratory Studies of the Pattern of Reproduction of the Isopod Crustacean Idotea balthica. Fishery Bulletin, 85, 377-380.

[19] Guarino, S.M., Gambardella, C. and De Nicola, M. (1993) Biology and Population Dynamics of Idotea balthica (Crustacea, Isopoda) in the Gulf of Naples, the Tyrrhenian Sea. Vie Milieu, 43, 125-136.

[20] Zaabar, W., Achouri, M.S. and Charfi-Cheikhrouha, F. (2013) Life Cycle and Population Dynamics of Idotea balthica basteri (Pallas 1772), Isopoda Valvifera from the Bizerte Lagoon (Southern Mediterranean Sea-Tunisia). Marine Ecology, 35, 367-376. http://dx.doi.org/10.1111/maec.12095

[21] Zaabar, W., Achouri, M.S. and Charfi-Cheikhrouha, F. (2014) Reproductive and Growth Strategies of Idotea balthica basteri (Pallas 1772) Population in the Bizerte Lagoon (Tunisia, Southern Mediterranean). Marine Ecology, 36, 585-594.

[22] Murphy, J. and Rieley, J.P. (1962) A Modified Single Solution Method for the Determination of Phosphate in Natural Water. Analytica Chimica Acta, 27, 31-36. http://dx.doi.org/10.1016/S0003-2670(00)88444-5

[23] Strickland, J.D.H. and Parson, S. (1965) A Manual of Sea Water Analysis. Bulletin of the Fisheries Research Board of Canada, 125, 1-203.

[24] Nicolaidou, A. (2007) Lack of Temporal Variability in the Benthos of a Coastal Brackish Water Lagoon in Greece. Mediterranean Marine Science, 8, 5-17. http://dx.doi.org/10.12681/mms.150

[25] Salemaa, H. (1979) Ecology of of Idotea spp. (Isopoda) in the Northern Baltic Sea. Ophelia, 18, 133-150. http://dx.doi.org/10.1080/00785326.1979.10425495 
[26] Kouwenberg, J. and Pinkster, S. (1985) Id. Part II. Life Cycles, Sexual Activity and Fecundity. Vie Milieu, 35, 79-92.

[27] Casagranda, C., Dridi, M.S. and Boudouresque, C.F. (2006) Abundance, Population Structure and Production of Macro-Invertebrate Shredders in a Mediterranean Brackish Lagoon, Lake Ichkeul, Tunisia. Estuarine, Coastal and Shelf Science, 66, 437-446. http://dx.doi.org/10.1016/j.ecss.2005.10.005

[28] Junoy, J. and Viéitez, J.M. (1990) Idotea chelipes (Pallas, 1966) (Crustacea, Isopoda) in the Ria de Foz (Lugo, Spain). Boletfn de la Real Sociedad Espanola de Historia Natural, 85, 87-97.

[29] Labourg, P.J. (1971) Cycle reproducteur d'un Isopode des étangs saumâtres de la région d'Arachon: Idotea viridis (Slabber). Vie Milieu, 22, 155-166.

[30] Merilaita, S. and Jormalainen, V. (2000) Different Roles of Feeding and Protection in Diel Microhabitat Choice of Sexes in Idotea baltica. Oecologia, 122, 445-451. http://dx.doi.org/10.1007/s004420050965

[31] Brylinski, J.M., Dagault, F., Davoult, D., Lampert, L., Meirland, A., Delpech, J.P., Maheux, F. and Vincent, D. (2006) Surveillance écologique et halieutique du site électronucléaire de Paluel. Rapport RST-LERN 06/01.

[32] Yoshida, M. (2012) Mobility of Contaminated Heavy Metals and Metalloids in Sediments Caused by Recent Industrial Activities: Cases in Algeria and Tunisia. 16th ICHMENT Symposium, Rome, 26 September 2012, 16 p.

[33] Bat, L., Sezgin, M., Gundogdu, A. and Culha, M. (1999) Toxicity of Zinc, Copper and Lead to Idotea balthica (Crustacea, Isopoda). Turkish Journal of Biology, 23, 465-472.

[34] Bouslama, M.F., Neto, J.M., Charfi-Cheikhrouha, F. and Marques, J.C. (2007) Biology, Population Dynamics and Secondary Production of Talitrus saltator (Amphipoda, Talitridae) at Korba Beach (East Coast of Tunisia). Crustaceana, 80, 1103-1119. http://dx.doi.org/10.1163/156854007782008595

[35] Pantoustier, G. and Prunus, G. (1977) Cycle biologique de l'isopode Jaera hopeana dans les milieux marins et lagunaires du Nord-Est de la Tunisie. Marine Biology, 43, 361-367. http://dx.doi.org/10.1007/BF00396929

[36] Leifsson, B.R. (1998) Life Cycles, Breeding Periods and Vertical Distribution of Idotea granulosa Rathke and I. pelagica Leache (Crustacea, Isopoda) on Icelandic Shores. Sarsia, 83, 1-13. http://dx.doi.org/10.1080/00364827.1998.10413664

[37] Mocquard, J.P., Legrand-Hamelin, E. and Souty, C. (1978) Influence de la salinité et de la température sur la fécondité des femelles et l'intersexualité d'Idotea baltica stagnea Tinturier Hamelin (isopode valvifère). Bulletin de la Société zoologique de France, 103, 47-57.

[38] Kouwenberg, J., Tan, S., Snoek, B. and Pinkster, S. (1987) Population Dynamics of Brackish Isopod Species (Crustacea) in the Lagoon System of Bages-Sigean (France). III: Reproductive Rates of Ldotea baltica and Ldotea granulosa. Vie Milieu, 37, 105-114.

[39] Salemaa, H. (1986) Breeding Biology and Microhabitat Utilization of the Intertidal Isopod Ldotea granulosa Rathke in the Irish Sea. Estuarine, Coastal and Shelf Science, 22, 335-355. http://dx.doi.org/10.1016/0272-7714(86)90047-8

[40] Marques, J.C., Martins, I., Teles-Ferreira, C. and Cruz, S. (1994) Population Dynamics, Life History, and Production of Cyathura carinata (Kroyer) (Isopoda: Anthuridae) in the Mondego Estuary, Portugal. Journal of Crustacean Biology, 14, 258-272. http://dx.doi.org/10.2307/1548906 